IDEAS BEHIND SYMBOLS - LANGUAGES BEHIND SCRIPTS 
Studia uralo-altaica 52

\section{Redigunt}

Katalin Sipőcz

András Róna-Tas

István Zimonyi 


\section{Ideas behind symbols - languages behind scripts}

Proceedings of the 60th Meeting of the Permanent International Altaistic Conference (PIAC)

August 27 - September 1, 2017

Székesfehérvár, Hungary

Edited by Ákos Bertalan Apatóczky

Szeged, 2018 
(C) University of Szeged,

Department of Altaic Studies,

Department of Finno-Ugrian Philology

Printed in 2019

All rights reserved. No part of this book may be reproduced, stored in a retrieval system, or transmitted in any form or by other means, electronic, mechanical, photocopying, recording or otherwise, without the prior permission in writing of the author or the publisher.

Printed by: Innovariant Ltd., H-6750 Algyő, Ipartelep 4.

ISBN: 9789633066638 (printed)

ISBN: 978-963-306-664-5 (pdf)

ISSN: 01334239 


\section{Contents}

Preface

Tatiana Anikeeva

Turkic Manuscripts and Old-Printed Books of the Lazarev Institute of Oriental

Languages: Exploring the History of Oriental Studies in Russia

Chen Hao

Bark: A Study on the Spiritual World of the Early Türks

Oliver Corff

Nations and Rivers: Their Status and Name in the Qingshi Gao Reflections on the

Draft History of Qing as a Source

Balázs Danka

A language behind the script A case study on the Pagan Oyuz-nāmä

Mihály Dobrovits

The Ogur Turks in Chinese records

Hsiang-Tai Kao

The field research on the Manchu inscriptions in Beijing

Bayarma Khabtagaeva

Some notes on kinship terminology in Yeniseian.

Kyoko Maezono

Japanese and Mongolian Usages of the Chinese Writing System

Dieter Maue - Mehmet Ölmez - Étienne de la Vaissière - Alexander Vovin

The Khüis Tolgoi inscription

Rodica Pop

The "five eyes pattern" tavan nüden hee

Maria Magdolna Tatár

Bortz and Membrok, etymology of two Cuman names from the 13th century.....107

Hartmut Walravens

Józef Kowalewski’s Letters to Bernhard Jülg.

Tana $\mathrm{Wu}$

One Language behind Two Different Scripts*

Hülya Yıldız

New Reading Proposal on the Eastern Face, Nineteenth Line of the Bilgä Qayan Inscription 



\title{
The Ogur Turks in Chinese records
}

\author{
Mihály Dobrovits \\ Şeyh Edebali University, Bilecik
}

In an earlier work of us ${ }^{1}$ we quoted a detailed list of these tribes preserved in the Suishu (隋書). ${ }^{2}$ On the other hand, data were also preserved in the Beishi (北史). ${ }^{3}$ Ligeti supposed that this list had to be composed cca. 600 AD. ${ }^{4}$ This can support the idea that the Chinese list of the Tiele tribes should be contemporary of our Byzantine sources from Priscus to Theophylactus.

According to our Chinese list the Tiele tribes living to the east of Fulin (拂菻, Roma, EMC $p^{h} u t-l i m$ ) were the Enqu (恩屈, EMC ?an- $k^{h} u t$; Hamilton: $\left.a n-k i n a t\right),{ }^{5}$ the Alan (阿蘭, EMC ?a-lan), ${ }^{6}$ Beiru (北裖, EMC pok-nuawk; Hamilton: pəkńźi wok), Fiuli (九離, EMC $k u w^{\prime}-l i a^{h} / l i^{h}$ or 'Nine $L i$ ), the Fu-wa7 伏溫, EMC buw'?wat) and the Hun (昏, EMC xwon). The tribe living along the coasts of the Volga ( Ätil, (阿得 Ade EMC ?a-tək) was the Suba (蘇拢, EMC so-bəit/be:t). ${ }^{8}$

According to Hamilton, $F u$-wa $a^{9}$ 伏溫, EMC $b u w^{2}$-?wat), Hun (昏, EMC $x w a n$ ) should be read as fiuliwu (九離伏) and Wahun. Wahun (溫昏, EMC ?wat-xwan: Hamilton: vat-xuən). It is a well-known fact, that in Old and Middle Chinese a

1 The Altaic World Through Byzantine Eyes: Some Remarks to Zemarchus' Journey to the Turks (AD 569-570), Acta Orientalia Academiae Scietiarum Hungarica LXIV (2011), 375-378.

2 Suishu 84, liechuan 49, (Shanghai, Commercial Press ed., 18a-18b); Zhongguo Shudian ed. 1879-1880; LMT (pp. 127-128); Hamilton (1962, pp. 26-27), his reconstructions are shown as Hamilton); the list of the Tiele tribes in this work and one of its later variants consisting of 15 tribal names preserved in the 14th century work Wenxian dongkao (文獻通考 'Comprehensive Examination of Literature') was analyzed also by Ligeti (1986, pp. 333-336), his readings and reconstructions are shown as Ligeti), and later by Golden (1992, pp. 155156); for a partial analysis in English see Mori (1985); in Turkish, see: Ögel (1945, pp. 80-83); later (based on the Tangshu) Taşağıl (2004, pp. 45-46); in Mongolian (the Eastern tribes only), Batsüren (2009, pp. 32-33).

3 Beishi quan 99, liechuan 87, Zhongguo Shudian ed. 3303. Beijing 1974.

4 Ligeti, L.: A magyar nyelv török jövevényszavai a honfoglalás elótt és az Árpád-korban, Budapest, 1985, 333.

5 In whom some scholars see the Onogurs, Golden (1992, p. 95); Ögel (1945, p. 80).

6 The only tribal name that can be certainly identified with that of the Alans, Ligeti (1986, p. 334); cf. also Alemany (2000, pp. 1, 401-403).

7 CP, f. $8^{\mathrm{b}}$.

8 Sußar (?), Hamilton (1962, p. 27).

9 CP, f. $8^{\text {b. }}$ 
foreign $-r$ was usually represented by $-t .^{10}$ Thus this name can be accepted as a

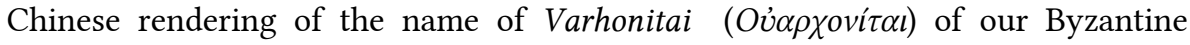
sources.

Beiru (北裖, EMC pak-nuawk; Hamilton: pak-ńźiwok) may be understood either as Northern $R u$ a still unidentifiable Chinese type tribal name, or, based on its phonetic form, a hypothetical Turkic tribal name *Buyay/q 'disturbed ones?', not attested by any other sources. ${ }^{11}$ As to Fiuli (九離 $k u w^{\prime}-l i \breve{a}^{h} / l i^{\mathrm{h}}$ ) it may be held for a Chinese version of the name Kutrigur $(<*$ Toqur Oyur). We can add that the numeral jiu (九) itself means 'nine' in Chinese. We can also assume that the change *Toqur Oyur> Kutrigur should appear also in the original name and not only in the Byzantine sources. Fu (伏 EMC buw $w^{\supset}$ Baxter OCh 338: bjuwH) hypothetically can be held for a somehow corrupted form of the name Utigur. This could fit into the historical environment, but, of course, it still remains uncertain. As to the Suba (蘇拢, EMC so-bait/be:t), with great probability they can be identical with the Sabirs.

We can reconstruct the list the following way:

Enqu (恩屈, EMC ?an-k $k^{h} u$; Hamilton: an-kiuat), Alan (阿蘭, EMC ?a-lan), Beiru (北裖, EMC pak-juawk; Hamilton: pok-ńźínok), Jiuli (九離, EMC $k u w^{3}-l i \partial^{h} / l i^{h}$ veya 'Dokuz $L i$ '), Fu 伏 $b u w^{\prime}$ ), Wahun (溫昏, EMC ?wat-xwan: Hamilton: uat-xuan), Suba (蘇拔, EMC so-bait/be:t).

Comparing our Byzantine and Chinese data we can see the following picture:

Certain identifications:

\begin{tabular}{|l|l|l|l|}
\hline Wahun, 㗐昏, & Enqu 恩屈, & Alan (阿蘭), & EMC so-boit/bc:t \\
EMC ?wat-xwan & EMC ?an- $k^{h} u t$ & EMC ?a-lan & Suba (蘇拢) \\
Warhun & Onogur & Alan & Sabir \\
\hline
\end{tabular}

Tentative identifications:

\begin{tabular}{|l|l|}
\hline $\begin{array}{l}\left.\text { Fiuli (九離 } k u w^{\prime}-l i \check{a}^{h} / l i^{h}\right) \\
\text { Kutrigur }\end{array}$ & $\begin{array}{l}\text { Beiru (北裖 EMC pak-puawk) } \\
{ }^{*} \text { Buyaq }\end{array}$ \\
\hline
\end{tabular}

Remaining uncertain:

$F u\left(\right.$ 伏 $\left.b u w^{2}\right){ }^{*}$ Utigur?

10 As it happened in the first syllable of Burxan, the Inner Asian form of the name of Buddha, which is fo (佛, 'Buddha') in Modern Chinese, cf.: Laufer (1916, p. 391); and Bailey (1931, p. 280); Doerfer: TMEN (II, pp. 261-262 [but), 283 [burxan)); according to Pulleyblank (1991, p. 96) the Early Middle Chinese form of this first syllable was still but.

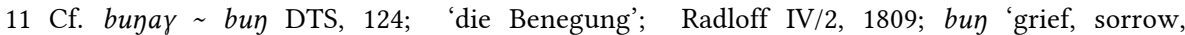
melancholy', Clauson $E D$ 347, печаль, скорб, страдание, тягость, забота DTA 124 bunqal 'дряхлый, лишенний сил, непригодный (?)', DTS 124. 
From the point of view of the historian, the most sensitive question is that of Wahun (溫昏), Warhun. Albeit the identification is being philologically clear, the historical whereabouts of this ethnonym still have some uncertain points.

The Turks, negotiating with the Byzantine authorities, argued that the Avars reaching the Carpathian Basin at 568 were Warhuns, falsely using the name of the Avars. In this preliminary report we have not the space to discuss this case in detail. ${ }^{12}$ On the other hand we may constate that the data preserved in our Chinese sources differ from those of the Byzantine authors. Even at a first glance one can realize that some of the Warhun tribes could have been present in the Eastern European region before the Avar conquest of the Carpathian Basin.

The most enigmatic tribal name is that of the *Bunaq. This word is a hapax legomenon not attested in any other sources. As we have seen above, Old Turkic buy usually means 'pain, sorrow'. In this meaning it was also passed into Hungarian ( $b u$ ' 'sorrow, grief; trouble' < Old Turkic buy/buך ' $i d$ '). ${ }^{13}$

Reading the Orkhon Inscriptions, one can assume that in these texts the stem buy is used in the meaning 'trouble' rather than 'sorrow'. Let us now see some examples: ${ }^{14}$

I. altun kümüš isigti qutay bunsiz anča bérür (S5)

They (i. e. the Chinese people) give (us) gold, silver and silk in abundance.

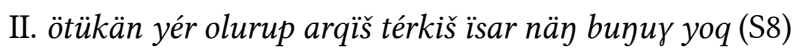

If you stay in the land of Ötükän and send caravans from there, you will have no trouble.

T II E 7 ne bujï bar ärtäči ärmis

(...) what kind of trouble would I have?

According to these data buy means 'trouble', therefore we can assume that our reconstruction 'Buyaq should mean 'troublesome or rebellious people'.

To sum up, we can constate that the data of our Chinese records can be analyzed and some of the tribal names can be identified on the basis of our earlier historical knowledge. Of course, these data need more detailed analysis that we are planning to prepare in the close future.

12 Dobrovits, M.: "They called themselves Avar" - Considering the pseudo-Avar question in the work of Theophylaktos, in: Compareti, M. - Raffetta, P. - Scarcia, G. (eds.): Ërān ud Anērān. Studies Presented to Boris Il'ič Maršak on the Occasion of His $70^{\text {th }}$ Birthday, Venezia 2006, 176183.

13 Benkő L. (Ed.-in chief): A magyar nyelv történeti-etimológiai szótára (Budapest 1984), I., 373.

14 If not shown otherwise we reflect on the readings and translations of Talât Tekin, A Grammar of Orkhon Turkic (Indiana University, Uralic And Altaic Series) Bloomington, 1968. 


\section{References}

Alemany, A. (2000): Sources on the Alans: a critical compilation, Handbook of Oriental Studies/Handbuch der Orientalistik, VIII, 5; Leiden-Boston-Köln.

Bailey, H. W. (1931): The word "But" in Iranian, Bulletin of the School of Oriental Studies 6, pp. 279-283.

Batsüren (2009): Өндөр тэрэгтнүҮд ба эртний түрэгүүд (VI-IX зуун), Улаанбаатар.

Beishi quan 99, liechuan 87, Zhongguo Shudian ed.. 3303. Beijing 1974.

Benkő L. (Ed.-in chief) (1984): A magyar nyelv történeti-etimológiai szótára. Budapest.

Clauson, Gerard, Sir (1972): An Etymological Dictionary of Pre-Thirteenth Century Turkish, Oxford.

Dobrovits, M. (2006): "They called themselves Avar" - Considering the pseudoAvar question in the work of Theophylaktos, in: Compareti, M. - Raffetta, P. Scarcia, G. (eds.): Ėrān ud Anērān. Studies Presented to Boris Il'ič Maršak on the Occasion of His $70^{\text {th }}$ Birthday, Venezia, 176-183.

Dobrovits, M. (2011): The Altaic World Through Byzantine Eyes: Some Remarks to Zemarchus' Journey to the Turks (AD 569-570), Acta Orientalia Academiae Scietiarum Hungarica 64, 375-378.

Doerfer TMEN: Doerfer, G. (1963-1975) Türkische und mongolische Elemente im Neupersischem I-IV, Wiesbaden.

Наделяев, В. М. - Насилов, Д. М. - Тенишев, Э. Р. - Щербак, А. М. (ред.) (1969) Древнетюркский словарь, Москва.

Golden, P. B. (1992):: An Introduction to the History of the Turkic Peoples. Ethnogenesis and State Formation in Medieval and Early Modern Eurasia and the Middle East, Wiesbaden.

Hamilton, J. R. (1962): Toquz-Oyuz et On-Uyyur, fournal Asiatique 102, 23-63.

Laufer, B. (1916): Burkhan, The Journal of the American Oriental Society 36, 390395.

Ligeti, L. (1985): A magyar nyelv török jövevényszavai a honfoglalás elött és az Árpád-korban, Budapest,.

Mori, M. (1965): On Chi-li-fa 俟利發 (Elteber/Eltebir) and Ch'i-chin 俟斤 (Erkin) of the T'ieh-lê 鐵勒 Tribes, Acta Asiatica, 9, pp. 31-55.

Ögel, B. (1945): Göktürk yazıtlarının « Apurım » ları ve « Fu-lin » problemi, TTK Belleten 9, 63-87.

Pulleyblank, E. G. (1991): Lexicon of Reconstructed Pronunciation in Early Middle Chinese, Late Middle Chinese, and Early Mandarin, Vancouver 1991. 
Radloff W. (1911): Versuch eines Wörterbuches der Türk-Dialekte IV/2, St.Pétersbourg.

Suishu 84, liechuan 49, (Shanghai, Commercial Press ed., 18a-18b); Zhongguo Shudian ed. 1879-1880, Beijing, 1974.

Taşağıl, A. (2004): Çin kaynaklarına göre eski Türk boyları. MÖ. III-MS X. asır, Ankara.

Tekin, T. (1968): A Grammar of Orkhon Turkic, Bloomington. 